\title{
Ethnomycological Conspectus of West African Mushrooms: An Awareness Document
}

\author{
Osemwegie Omorefosa Osarenkhoe ${ }^{1 *}$, Okhuoya Aroye $\mathrm{John}^{2}$, Dania Akande Theophilus ${ }^{2}$ \\ ${ }^{1}$ Department of Biological Sciences, College of Science and Engineering, \\ Landmark University, Omu Aran, Nigeria \\ ${ }^{2}$ Department of Plant Biology and Biotechnology, Faculty of Life Sciences, \\ University of Benin, Benin City, Nigeria \\ Email: *osemwegie.omorefosa@landmarkuniversity.edu.ng, \\ okhuoya@yahoo.com, theo12ng1@yahoo.com
}

Received October 22, 2013; revised November 22, 2013; accepted November 29, 2013

Copyright (C) 2014 Osemwegie Omorefosa Osarenkhoe et al. This is an open access article distributed under the Creative Commons Attribution License, which permits unrestricted use, distribution, and reproduction in any medium, provided the original work is properly cited. In accordance of the Creative Commons Attribution License all Copyrights (C) 2014 are reserved for SCIRP and the owner of the intellectual property Osemwegie Omorefosa Osarenkhoe et al. All Copyright (C) 2014 are guarded by law and by SCIRP as a guardian.

\section{ABSTRACT}

The ethnological knowledge of mushrooms despite its millennial existence and its empirical documentation are more recent phenomena. In Africa, the knowledge of their historical uses as food, medicine, source of income and small scale businesses, and the sociological impacts (myth, culture and spirituality) are apparently threatened due to slow ethnomycology research drive. The poor identification and documentation of edible and medicinal species of mushrooms in many developing nations have created some degrees of inconsistencies in their usages relative to folk medicine practice, food and mythological beliefs. Their relevance in modern day pharmaceutics and nutraceuticals is a product of human experimentation over time. Factors that may be anthropogenic, ethnographic, ethnoecological/environmental have been implicated in mushrooms underutilization and under-exploration of mushrooms in West Africa. Ethnomycological literatures on West Africa are scant, random, are limited in scope and fraught with taxonomic inconsistencies. This paper is based on extant ethnomycology treatise and aims at representing an integrative knowledge of useful mushrooms of West Africa and their uses vis-a-vis indigent cultures.

\section{KEYWORDS}

Ethnomycology; Conspectus; West African Mushrooms; Explorative Profiting

\section{Introduction}

While interaction of humans and mushrooms dated back to many millennia and peaked in the food gathering era, the documentary evidence of ethnomycological knowledge is a more recent conception. The earliest accounts of ethnomycology emerged within the century and became a migrated discipline from ethnobiology (peoplebiota-environment interactions) and ethnobotany (cultural uses of plants). Controversially, it also overlapped with social science based disciplines like anthropology (study of human kind) and ethnography (empirical data on human society and culture). This concurred with the

*Corresponding author. views of [1]. Ethnomycology popularises more the diversity of useful mushroom species over the poisonous ones and provides insight into their sociological impacts on human behaviours, indigenous uses and the yet misunderstood influence of ethnoecology in mushrooming. Furthermore, it emphasizes mushroom-forming fungi (mushrooms, macrofungi) over their microscopic (conidial) counterparts, contextualizing them as the essence of ethnomycological knowledge around the world. Ethnomycology derived from human insatiable and dynamic desire to improve his food and medicine base, civilization and culture. It is a representation of a balanced tripartite ecological relationship between humans, mushrooms and abiotic components of a complex ecological 
system. Consequently, this formed the basis for understanding the unquestionable importance of fungi to past and present civilization globally [2]. The sustainable but rapid drive for mushroom domestication as a better alternative to the ancient practice of mushroom hunting in the wild remained controvertible in West Africa. It is therefore logical to presume that domestication of wild edible mushroom would help preserve ecosystem dynamics, and its associated goods and service delivery capacity. It also reduces risks associated with hunting mushrooms in the wild. Mushroom domestication has attracted donor-funded projects of the Food and Agricultural Organization (FAO) of the United Nations to Africa to assist governments in combating issues of poverty and food security. These initiatives, especially those deploying valuable species of mushrooms were however cockeyed to central, east and South African nations with limited representation in West Africa. It is incontrovertibly possible to ascribe this to limited mushroom research collaboration, slow publication of mycological works and far-in-between revision of existing inventories of both valuable and valueless mushrooms. Many published ethnomycological works from Asia, South America, Canada and America are prolific and represent diverse areas of mushroom knowledge that includes cultivation [3], entheogenics (spirituality and mythological values), mycopharmaceuticals, mycophagy, nutriceutics [4,5], folk mushroom taxonomy and the dynamics of inherited folk knowledge of mushrooms [6,7]. The intrinsic sociological factors driving the heritage of traditional based knowledge of mushrooms along generational lineage and culture transformation were outlined by Garibay-Orijel et al. [7] to include experimentation, innovation transculturation, acculturation and syncretism. Although, these and their influences on human behaviour toward edible mushrooms require further studies, they are seldom the focus of ethnomycological works in the region. A few of these studies, though theoretically derived from agelong interaction between humans and the environment, have not presented adequate insight to humans' cultural attitudes and idiosyncratic emotions toward fungi (mycophobia and mycophilia). This is in addition to the influence of psychedelic fungi on religion and knowledge heritage of local mushroom $[8,9]$.

West Africa lies close to $10^{\circ}$ East longitude and composed of 16 sovereign countries spread over a land area of $140,000 \mathrm{~km}^{2}$, all sandwiched by the Atlantic ocean on the South border and the Sahara desert on the North side. The region accommodates $3.4 \%$ of the over 1.0 billion African population with an average population density of approximately $175 / \mathrm{km}^{2}$. The sub-region is endowed with rich gradation of tropical rainforests and verse savannah woodlands (Figure 1). This made the region potentially

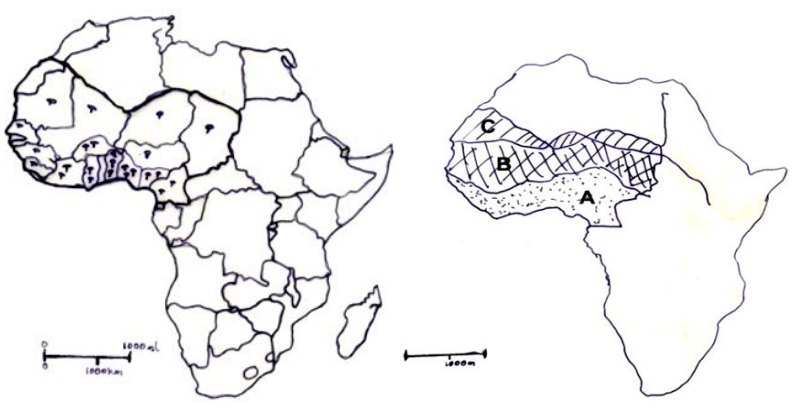

Figure 1. Map of West Africa showing the ethnomycology spread pattern, apparent mycophilic status (scanty, moderate, and average) and vegetation respectively. $A=$ Tropical Forest, B = Savannah woodlands, C = Savannah Grassland.

fertile for foreign donor-funded conservation and mushroom research initiatives. The historical transcultural and accultural dynamics of the West African people predates colonial dominance and accounted for the recognizable similarities in their culture, cuisines, religion, dress style and music in the region. Although sedentary farming began around the fifth millennium, it is however yet unclear when mushroom commodification began in West Africa neither is the extent to which has influenced the dynamics of mushroom knowledge and heritage, uses, and mycophagy across West Africa. More information is therefore required to fully understand how the improving trend of mushroom commodification bares on indigenous mushroom knowledge and culture evolution.

Traill et al. [10] recognizes the relevance of rainfall to species availability, composition and spread, and as the most important denominator that separates West Africa from Central, East and South African sub-regions. In addition, the rich vegetation covers that characterized the West African region could have accounted for the high population density. This correlates with logical thoughts that pitched humans' settlement in places that provide easy access to food, fruits, water and security as typified by the overwhelming presence of forests, rivers and tributaries respectively in the region. The climate condition of the region according to Kauserud et al. [11] supports rich mushroom development and diversity. Suffice to say that West Africa incontrovertibly ranked among other parts of the world and recognized as one of the major hotspots of fungi. Current polemic world fungal diversity estimate is based on the ratio of 5:1 (higher plants to fungus) extrapolation of Hawksworth [12]. In addition, using documented plant species data, Hawksworth [13] reported a total of 140,000 global species of macrofungi for which only $10 \%$ were already documented and an a priori estimate of 35,000 - 40,000 remaining "unknown" species as reported by Mueller et al. [14]. He ascribed an estimated 25,000 known species of macrofungi to Africa. Similarly, Rossman [15] gave 10\% of Hawksworth (2001) conser- 
vative estimate to be between 53,000 and 110,000 macrofungi out of which over 2800 was reported by Boa [16] to be used worldwide. This is however at variance with Germishuizen and Meyer's [17] list of flora of the South African regions consisting Botswana, Lesotho, Namibia, South Africa and Swaziland. There is still no correct estimate of the diversity value of mushrooms and macrofungi represented in Africa. Efforts in this direction may be confounded by discontinuous revision of existing lists of mushroom taxa and their unrecorded traditional uses. This study while appreciating commonalities in mushroom culture, especially mycophagy and the abysmal level of unrecorded uses of mushrooms, marvel at the state of ethnomycology research in the region.

Emerging reports on ethnomycology studies in many parts of Africa are varied, incoherent, culture based, skewed, biased against mushrooms of unknown uses. It is ecology dependent and showed comparative degree of inconsistency in their use as food, source of income and medicine [18-20]. In addition, African ethnomycological works are reflection of the depth of understanding of the potential values inherent in mushroom genetic resource and strongly influenced by folk taxonomy. It could be philosophically presumed that the over-shadowing effect of traditional nomenclature practice in most African suburbs may have constrained the development of ethnomycology, mushroom diversity and taxonomy researches, and become the apparent root cause of inconsistent global scientific nomenclature. The dominance of folk taxonomy in West African ethnomycology is attributed to reasons that may include inherited cultural knowledge, access to modern taxonomy information, and dearth of trained mushroom taxonomists. The engendered practice of ascribing traditional (dialectic) name only to the useful mushrooms and rarely the poisonous ones or those with unknown uses mushrooms have also limited the quality of ethnomycological information from West Africa. Compared to recorded advancements in other ethnoscientific studies of botanical and zoological origins, the theoretical and dimensional utility of mushrooms in West Africa is not yet fully represented in ethnomycology literatures [21]. Invariably, it can be summated that the formal institutionalization of mycology (mycodiveristy, ethnomycology, mycosystematics, mycoecology, etc.) research structure is still developing and incongruous with reports affirming Africa as a potential biodiversity hotspots of mushroom diversity with undocumented and cryptic taxa [14,18,22]. The reports of Gryzenhout et al. [22], Labarère and Menini, [26] and Crouse et al. [27] on African mushrooms were limited to central and east Africa. There are however few ethnomycology reports on Nigeria [18,23], Burkina Faso [24,25], Cameroon [2630], Ghana [31], Togo [32], Ivory Coast [33], Gabon [34], and Bénin [35,36]. This document is aimed at evoking consciousness on the state of ethnomycology information and knowledge of heritage useful mushrooms (edible and medicinal mushrooms) and the influence of mushroom commodification and domestication on the evolution of culture in the West African region. It further served as a basic integrative approach document to understanding ethnomycology in the region.

\section{Collection and Uses of West African Mushrooms}

Mushrooming, mushroom foraging or hunting is an ancient practice which predates the emergence of ethnomycology as a discipline in many parts of the world. It refers to the habit of picking edible mushrooms from the wild and surrounding woodlands sensu lato for food. The oldest account of this practice in West Africa was putatively glimmered by Walker [37], Zoberi [38,39] and Oso [40,41]. Mushrooms were recorded to be obtained from woodlands (forests, plantations), farmlands and grasslands along with other non-wood forest products (NWFP). Their presence has also been documented around and within human dwellings [27]. This could have been made possible by the dynamics of prolonged mutually beneficial interactions down evolutionary lane that logically caused improved survival and adaptive mechanisms reflecting in their growth, nutritional diversity, reproductive capacity and clock, habitat range and dispersal characteristics. The knowledge of edible mushrooms is limited to their visible fruit bodies and genealogically transcends generations since the food gathering by humans. Although, the knowledge and traditional uses of their invisible vegetative mycelia forms remains dearth, Isikhuemhen and Okhuoya [42] reported the use of an indigenous mushroom (Pleurotus tuber-regium) sclerotia in soup making and the treatment of mumps in Nigeria. Philosophically, it could be assumed that current uses of wild mushrooms were products of ancient experimentations and possibly opportunistic discovery by humans despite confounded geneology of their cultural uses. The culture of collecting wild edible mushrooms (WEM) in woodlands, farmlands and meadows which is hitherto engaged in by locals of lower socio-economic status dwelling in rural villages and suburbia for food subsistence is now relatively shifting beyond that to income generating small scale business ventures through their commodification. Multidimensional use has elevated mushrooms to cash crops status that are well priced as food, medicine, and a wide range of other potential uses as mycofungicides, biofertilizers, novel drugs, animal feed supplement and bioremediants and tool in the healthy management of agroforests [4,43,44]. While there are inadequate accounts of traditional uses of 
mushrooms despite report by Boa [45] of stronger mycophilia in West Africa, large volume of information however existed on their usage in Europe, Asia, North and South America where traditional vocation of mushroom picking is fading into obscurity. Economically viable and sustainable conception by developed countries of mushroom domestication, subsequent dependence on them as the primary source of edible mushrooms and forest protection/conservation legislature have gradually subverted the ancient practice of their collection from the wild. Suffice to say little or no integrative ethnomycological information on mushroom traditional uses, cuisines and complete list of useful macrofungi in Africa or West Africa existed. Collaborative efforts are therefore required under the platform of either the African Mycology Association (AMA) or the African Society for Edible and Medicinal Mushrooms (ASEMM) to capture the representative macrofungi species (both valuable and mycoflora of unknown uses) of Africa with a view to revising their global representation.

The people of West African sub-region still rely on wild edible mushrooms for their livelihood especially as a low-cost alternative for animal proteins and flavouring in diets. In addition, they represent a venerable source of subsistent income and incontrovertible raw material in local traditional medicine practice. Women and children according to Guissou et al. [25] and De Román et al. [46] are more involved with the vocation of picking wild edible mushrooms either for sale at local markets, cooking, dye extraction for rural cosmetics or hair dye, voodooism (mysticism) or for religious rites. This concurred with the report of Garibay-Orijel et al. [7] and Okhuoya et al. [18], and raised the question on the influence of gender on the heritage of local knowledge of mushrooms. Despite the paucity of reviews linking gender and ethmycological knowledge, the role of local African women and children cannot be delineated from the economy of the homestead. It is therefore logical to assume that women wield better knowledge of edible mushrooms as well as the poisonous ones, their characteristic and identification features which are mostly macroscopic than men. In addition, they also have the best capacity to distinguish edible and poisonous mushrooms, knowledge of their spatial distribution in terms of habitat, phenology and associated substrate(s), processing (handling, drying and cooking) and appropriate local cuisine uses. The emergence of commidification of collected edible mushrooms at rural markets could also be linked to the innovation of local suburban women and may be one of the theoretical causes of secrecy of information observed in the West African region. Although the role of gender in the evolution of folk taxonomy is still unclear, it could be hypothesized that mushroom collectors derive local (indigenous) names of various edible mushrooms from their habitat, season/phe- nology, shape, colour, folktale and uses [23,28,29,47]. On the contrary, a study by Akpaja et al. [48] reported that aged (50 - 75 years old) men in the suburbs also command relatively sufficient knowledge of indigenous wild edible and poisonous mushrooms. Although, the influence of occupation type on the depth of indigenous knowledge of wild edible mushrooms remains unclear, the distribution of this knowledge logically relates to occupation. Personal communication with some mushroom biologists and observation within the region affirmed high knowledge of mushroom heritage in local men linked to forest-related occupations like game hunting, farming, palmwine tapping, foresters, firewood collector, herbalists, fruits, latex, palmfronds and nuts gathers. It is invariable philosophical to deduce that uses of wild mushrooms in the region are limited only to medicinal, psychoactive (psychedelic or entheogenics), cosmetological (colouring of hair), flavouring and food. Uses this could be as a result of ignorance of other uses due to poor explorative ethnomycological research that provide values for hitherto valueless species of wild mushrooms. The appearance of edible mushrooms, majority of which are fleshy or non-xeromorphic, in West Africa is restricted to the rainy season, planting seasons (mostly in farm communities) and within the broad canopy woodlands. This has consequently compounded their availability and affected peoples' behaviour, diets and mushroom utility pattern. In many farming communities, around West Africa, farming season represents low availability of food hence mushrooms were the most favourable option for overwintering the abysmal food season.

Millions of years of cultural interaction among the West African people has evoked commonality in mushrooming pattern, mushroom recipes, folk believes, socioeconomic class and age of mushroom hunters, and uses of mushroom collected. In addition, many believed that several wood decaying saprotroph or tree associated mycorrhiza mushrooms are edible because of a genealogical conception derived from the "wholesome ingestible value" of trees. Thus every part of a tree serves as food per time to different spatial and temporal organisms. The spread of the tropical forests (rain, deciduous and mangroves) vegetation across the nations of the sub-region (Figure 1) coupled with associated coastal and geologic features complimented the conjecture by Oso [41] that over $75 \%$ of the tribes in the region are inheritably mycophilic. A paradigm shift in peoples’ mycophagic behaviour from mycophily among rural suburban areas to mycophoby in city or urban dwellers is also an observable trend in the region. It is imperative to measure the impact created by the pressure of mushrooms collection in Africa on forest diversity, ecosystem dynamics and distribution of edible mushrooms with a view to identifying need for conservation or the evolution of 
legislature that protect the forests and rescue over-exploited mushrooms from eminent extinction.

Wild mushroom collection practice in the sub-region is largely forests linked, indiscriminate, and precludes any conceptualized plan for germplasm conservation, forest preservation nor consideration of the consequences of over-exploration and over-exploitation of mushrooms on forest ecosystems' functions, species composition, richness and diversity. Collected edible mushrooms are handled ex situ in almost similar manners and this may involve the careful removal of dust, cooking fresh and/or dried for eating or cooking at a later time. The methods of preserving or drying mushrooms which are rampant among the West African people include, sun-drying on a mat and in suspension over local hot coal pot or burning firewood stove, smoking and salting. Modern civilization and the introduction of electricity to diverse formally non-electrified suburbs in many West African communities have expanded the process of preserving edible mushrooms to include refrigeration. Depending on the morphology of collected wild edible mushrooms, the cap and the pileus (cap) may be separated prior to cooking or drying or cooked whole in the case of edible polypores. The reason for this practice is not fully understood but may either make for effective and fast drying or better still cooking which could be an unconscious strategy to detoxify (remove toxin) the mushrooms. Secrecy of in situ knowledge of many edible and medicinal mushrooms is also a common practice. Bounty harvests are sold for little subsistent income to tourists, hoteliers as well as mycophilic visitors from the cities. The pattern of marketing wild indigenous edible mushrooms however varies from one West African country to another and even amongst tribes. In Nigeria, Ghana and Bénin mushrooms are sold openly either carefully displayed on clean tables during village market days or hawked on trays along highways outside market days. They are displayed in different basket sizes correlating to their quantity and price, or mentally measured on trays. Even though the ancestral origin of indigenous knowledge of wild edible and medicinal mushrooms in the region remained an unsolved mystery, it cannot be separated from evolving understanding and consciousness of the people about their environment and instinctive propensity for food. Folk accounts associated with the accidental or opportunistic applications of wild mushrooms were rooted in traditional beliefs and myths. Some of these controversial beliefs that are fast becoming heresies include 1) any wild mushroom nibbled in situ by insects, rodents and some other form of animals qualify as food for humans, 2) any mushroom fed ex situ to a life chicken, pig, dog or any other domestic stock without deadly sick or death repercussion is edible for humans, 3) brightly coloured, heavily ornamented, funny shaped (e.g. Phallus pp.) and hypogenous mushrooms are associated with the gods and poisonous hence avoided, 4) pleasant smelly e.g. mealy mushrooms must be edible. Presumably products of human experimentations have enriched the knowledge of mushroom uses leading to their edibility acceptance or toxicity discernment. Consequently, this unbalanced knowledge or unwritten codes of wild useful mushrooms guide their collection, transcends generations, and engenders strong knowledge of dialectically variable folk taxonomy and classification across the region [49]. More understanding and documentation of folk knowledge is required for the revision of the current information base on West Africa. The representation of hitherto undocumented usages, or discovery of fresh/cryptic mushroom taxa or setting record straight about mushroom taxa that were previously identified wrongly call for further collaborative studies.

\section{Wild Edible and Medicinal Mushrooms}

Folk taxonomy of edible mushrooms is restricted to local information distribution and based on different language versions that vary dialectically with tribe and interpretation. This has been found to be inconsistent, amenable to change by transculturation or acculturation. Consequently, the use of local names of wild edible mushrooms will be sparingly discussed in this paper.

Limited accounts of wild edible and medicinal mushroom taxa with saprobic and ectomycorrhizal habits have been reported from tropical regions of West Africa [50]. Although, there is yet no consolidative approach and empirically estimated value of edible mushrooms for the sub-region comprising 16 nations, some degree of ethnomycological information on Republic of Bénin, Burkina Faso, Cameroon, Cote d'Ivoire, Ghana, Ivory Coast, Nigeria and recently Togo existed in mycological literature [18,25,29,30,51]. A survey of ethnomycological treatise reflected low level of mushroom cultivation practices and production outputs, and poor inventory of various mushroom diets or useful wild edible mushroomforming fungi. It may therefore be ideologically assumed that information on mushrooms is restricted to only the useful taxa. The current ethnomycological information on West African edible and medicinal mushrooms is an uncomplimentary representation as lots of useful mushrooms and their diverse utility in some locations within the sub-region are still elusive as well as undocumented. Invariably, some inventorial accounts alluded to the region included Rammeloo and Walleyn [34], De Kesel et al. [35] and Zoberi [38]. There is also no baseline ethnomycology account on Mali, Chad, Niger and Mauritania which were far afield in semi-desert and grassland vegetations. This observation which is in concordance with a study by Nwordu et al. [23], demonstrated the impact of desertification vis-a-vis forestation on the availability of 
wild edible mushrooms. This invariable explains the rarity of ethnomycology literatures from the this parts of West Africa. In addition, the lack of a recognizable mushroom culture and the peoples' apparent disinterest in mushrooms generally may also account for this. Distribution and pattern of rainfalls are cardinal to the growth dynamics, species composition and diversity of mushrooms. Consequently, it defines the availability and the complexity of people-mushroom relationship. Similarly, it is observed that countries such as Gambia, Liberia and Guinea Bissau which are located within the woodlands (tropical rain and deciduous forests) region of West Africa disputatively lack ethnomycological data (Figure 1). While the reasons for this are discordant with the aforementioned, they are unconnected to the availability of useful mushrooms and poor rainfall patterns. Poor mushroom representation and uses in the regions may be invariably linked to a combination of factors that may ideologically include (not exclusively) undocumented ethnomycology research, endemic mycophobic culture, paucity of mycologists, limited traditional mushroom cuisines, disintegrative cultural mushroom heritage, political instability and occupation besides non-availability of mushrooms. This disagrees with claims in literatures that mycophagy is prevalent in the tropical rain forests and woodland savannahs areas of the world with huge agroforestry base [1]. It is also observed that mycophobic culture apparently suffuses desert nations within the region most of which parade lifestyles that derive less benefit from the verse range of ambient forests. Consequently, it can be hypothesized that indigenous mushroom culture and the knowledge base involving their multidimensional uses and their diversity have suffered many years of neglect. Furthermore, these have had negative consequences on the overall global knowledge and diversity representation of African mushrooms. Suffice to say that the region promises many yet unknown species of mushrooms with valuable potential but equally unknown uses. This study recognizes the lack of ethnomycological information from some of the West African nations unconnected with lack of mycophagy culture or use of mushrooms and advocates more study of indigenous mushroom heritage research in such places.

The study also showed marginal variations in mycophagy culture, the choice and representative composition of useful mushrooms. Auricularia auricular-Judae, Calvatia cf. cyathiformis, Daldinia concentrica, Ganoderma lucidum, L. tuber-regium Syn. Pleurotus tuber-regium, Schizophyllum commune, Termitomyces microcarpus, $T$. robustus, T. striatus, Volvariella volvacea are common organoleptic (or gastronomic) and folk medicine mushrooms in the region (Table 1). The use of Phallus species in Nigeria, Amanita strobilaceovolvata in Ghana, $\mathrm{Hy}$ grophoropsis aurantiaca and $H$. mangenotii in Cote
D’Ivoire, and Tubosaeta brunneosetosa as food are isolated examples of endemic uses that were stricto sensu preferential neglected as food in other cultures even when they are available in the wild. Although, the variations and relative endemism of certain edible mushrooms may be rooted to the traditional lifestyle and dietary habits of the people, nevertheless further understanding is required on the stochastic sociological and anthropological dynamics of the West African mushroom diet culture. The interplay of correlated physical factors driving the emergence of this observed cultural differences and similarities in mycophilic habits as well as traditionally accepted variety of selected wild culinary mushrooms is not fully understood. A few mushrooms hitherto categorized in other places within and outside West Africa as poisonous e.g. Chlorophyllum molybdites, Amanita spp., Agrocybe spp. and Coprinus spp. were reported as edible in other cultures within the W. African region. The reason for this inconsistency is not yet fully understood. However, logical but differential thoughts abound in many ethnomycological literatures. The most popular ideological reason alluded to the paucity of mushroom taxonomy expertise and/or misidentification of traditional wild edible and medicinal mushrooms in many developing countries. This has negatively affected the quality of ethnomycological works, global representation of both edible mushroom taxa and mushroom taxonomists of West African extract position on the board of the Nomenclature Committee for Fungi (NCF) and the International Commission for the Taxonomy of Fungi (ICTF). Furthermore, it has confounded integrative cataloguing of wild edible and medicinal mushrooms of West Africa. The popular approach to ethnomycology research in the region relies on some of the more common literature guide or pictured monographs from the more advanced inventory of Europe and America for the identification of wild edible mushrooms. Not employing the benefits of molecularly identification technology could have also accounted for the inconsistency in earlier mentioned. Furthermore, the influence of resident phytochemicals and/or the level of heavy metal contamination that characterizes the environment/substrate of domiciliary mushrooms were reported as possible sources of chronic poisoning and has also been implicated in the questionable edibility status of certain mushrooms $a b$ initio poisonous [23,46,52]. The peculiar feeding habit (extra-cellular digestion) of many useful saprotrophic mushrooms which invariably has the highest representation of wild poisonous ahead of mycorrhiza mushrooms strongly supported this logical derivation. Consequently further understanding of the mechanisms of metabolism or bioaccumulation of mushrooms' nutritional intakes is required to underscore the safety concerns relating to handling, cooking or eating of raw mushrooms. The impact of misidentification of edible mushroom taxa 
Table 1. Some wide spread edible mushrooms that dominate ethnomycology literatures of West African origin.

\begin{tabular}{|c|c|c|c|c|}
\hline $\mathbf{S} / \mathbf{n}$ & Scientific name & Uses & Country & Source \\
\hline 1 & Agaricus groossenniae & Food & Bénin, Ivory Coast, Ghana, Cameroon & {$[26,30,35]$} \\
\hline 2 & Amanita sp & Food and folk medicine & Bénin, Ivory Coast, Nigeria, Senegal & {$[18,24]$} \\
\hline 3 & Auricularia auricula-Judae & Food and folk medicine & Bénin, Cote D’Ivoire, Ghana, Ivory Coast, Nigeria & {$[23,34,57]$} \\
\hline 5 & Calvatia cf. cyathiformis & Food and folk medicine & $\begin{array}{l}\text { Bénin, Cameroon, Cote D’Ivoire, } \\
\text { Ghana, Ivory Coast, Nigeria, Senegal }\end{array}$ & {$[16,28,58,59]$} \\
\hline 6 & Cantharellus congolensis & Food & Bénin, Ivory Coast, Ghana, Cameroon, Nigeria, Senegal & {$[26,30,35,59]$} \\
\hline 7 & C. platyphyllus & Food & Bénin, Ivory Coast, Cameroon, Nigeria & {$[16,23,57]$} \\
\hline 9 & Chlorophyllum cf. molybdites & Food & Ivory Coast, Cameroon and Nigeria & {$[18,24]$} \\
\hline 10 & Coprinus africanus & Food & Burkina Faso, Ivory Coast, Nigeria & {$[16,34]$} \\
\hline 11 & Coprinus s.l. sp & Food & Burkina Faso, Ivory Coast, Nigeria & {$[18,34]$} \\
\hline 12 & Daldinia concentric & Folk medicine & $\begin{array}{l}\text { Bénin, Cameroon, Cote D’Ivoire, Ghana, } \\
\text { Ivory Coast, Nigeria, Senegal }\end{array}$ & {$[26,30,34,35]$} \\
\hline 13 & Ganoderma lucidum & Folk medicine & $\begin{array}{l}\text { Bénin, Cameroon, Cote D’ Ivoire, Ghana, } \\
\text { Ivory Coast, Nigeria, Senegal }\end{array}$ & {$[16,28,58,59]$} \\
\hline 14 & G. applanatum & Folk medicine & Cameroon, Nigeria & {$[23,30]$} \\
\hline 15 & Macrolepiota procera & Food & Cameroon, Guinea, Nigeria & {$[26,30,35]$} \\
\hline 17 & Lentinus squarrosulus & Food and folk medicine & Cameroon, Ghana, Nigeria & {$[34]$} \\
\hline 18 & L. subnudus & Food & Ivory Coast, Nigeria & {$[59]$} \\
\hline 19 & $\begin{array}{l}\text { L. tuber-regium Syn. } \\
\text { Pleurotus tuber-regium }\end{array}$ & Food and folk medicine & $\begin{array}{l}\text { Bénin, Cameroon, Cote D’Ivoire, Ghana, } \\
\text { Ivory Coast, Nigeria, Senegal }\end{array}$ & {$[23,34,57]$} \\
\hline 20 & Pleurotus pulmonarius & Food & Bénin, Cameroon, Nigeria & {$[29,51,61]$} \\
\hline 21 & Phlebopus sudanicus & Food & Bénin, Burkina Faso & {$[62]$} \\
\hline 22 & Psathyrella atroumbonata & Food & Cameroon, Nigeria & {$[18,34]$} \\
\hline 23 & Russula sp & Food and folk medicine & Bénin, Cameroon, Nigeria & {$[18,29,36]$} \\
\hline 24 & Termitomyces microcarpus & Food and folk medicine & $\begin{array}{l}\text { Bénin, Cameroon, Cote D’Ivoire, } \\
\text { Ghana, Ivory Coast, Nigeria, Senegal }\end{array}$ & {$[16,28,58,59]$} \\
\hline 25 & T. robustus & Food and folk medicine & $\begin{array}{l}\text { Bénin, Cameroon, Cote D’Ivoire, Ghana, } \\
\text { Ivory Coast, Nigeria, Senegal }\end{array}$ & {$[16,28,58,59]$} \\
\hline 26 & T. striatus & Food and folk medicine & $\begin{array}{l}\text { Bénin, Cameroon, Cote D’Ivoire, Ghana, } \\
\text { Ivory Coast, Nigeria, Senegal }\end{array}$ & {$[23,29,51,57]$} \\
\hline 27 & Schizophyllum commune & Food and folk medicine & $\begin{array}{l}\text { Bénin, Cameroon, Cote D’Ivoire, } \\
\text { Ghana, Ivory Coast, Nigeria, Senegal }\end{array}$ & {$[16,28,59]$} \\
\hline 28 & Volvariella esculenta & Food & Bénin, Cameroon, Cote D’Ivoire, Ivory Coast, Senegal & {$[26,30,35]$} \\
\hline 29 & V. volvacea & Food and folk medicine & $\begin{array}{l}\text { Bénin, Cameroon, Cote D’Ivoire, Ghana, } \\
\text { Ivory Coast, Nigeria, Senegal, Togo }\end{array}$ & {$[16,48]$} \\
\hline
\end{tabular}


in the region has equally undermined domestication and commodification drive [53]. Although, the empirical study of mushroom poisoning is scant and incidences of toxicomycosis, however insignificant are seldom documented, poisoning occurs at an insignificant level (from personal interactions). This may be attributed to the eclipse effects of traditional health care on orthodox practice in most local settings where mycophagy is dominant. Inherited or novated mushroom culinary behaviours linked with length of cooking, refraining from eating raw (uncooked) food and combining native alcoholic beverages with mushroom meals could have also accounted for the reduced incidences of toxicomycosis in West Africa. It is also theoretically conjectured that the differences in the complex physiological tolerance reaction connected to races and/or their genetic variability may have accounted for the observed contradiction of the poisonous nature of certain mushrooms reported in literature [18]. This underscores the need for a coordinated taxonomic order of one fungus = one name reported by Norvell [54] and Hawksworth et al. [54] which was encouraged by the new body for the International Code of Nomenclature for Fungi (ICNF).

In summary, the West African region may represent a diversity hotspot for more novel poisonous and nonpoisonous morphotypes (or forms) hitherto undocumented in literature [22]. This strongly suggests further need for fungi diversity characterization of locally indigenous species in the West African sub-region as a priority for their effective and potential utilization as well as conservation initiatives.

The West African region may apparently be credited with a broad range of wild edible mushrooms some of which remained poorly identified or better still unreported. Consequently, the total wild mushroom resources of the region remained under-represented in literature [14, 20], under-explored for the improvement of civilization $[18,27]$, threatened by urbanization and anthropogenic activities [25,55,56], and recession of inherited and/or indigenous knowledge of edible and medicinal mushrooms taxa and their corresponding uses. This paper is therefore aimed at creating the awareness for the rescue of the rich indigenous knowledge, mycophilic culture and wild edible mushroom biogenic resources in the subregion.

\section{The State of Mushroom Domestication}

Mushrooms are appreciated as cheap sources of rich proteins and other food nourishments. While they remained unquestionably popular in the preparation of many delicacies across the West African sub-region, their proximate and nutrient contents may not be fully comprehended by most rural mycophagists $[63,64]$. This is in addition to being a preferred alternative to animal proteins like red meats and fishes, and synthetic flavouring condiments. There collection, local commodification and preservation has driven the priority for their domestication (cultivation) in the course of time and also curbed safety concerns for children and women involved in the vocation of picking wild edible mushrooms for either food or meagre income. In many developing countries, especially in the West African region where mushroom hunting has became a prevalent practice among youths, women and children, the associated risks from such activity cannot be underrated [18]. Idu and Osemwegie [65] outlined some of the risks to include exposure to wild animals and potentially toxic exudates of plants, poisonous bites from insects, and mycotoxicosis and mycetisma from ingesting or handling wild mushrooms. The practice also overburdens many woodlands causing fragmentation and disrupting forest ecosystem resilience. Edible mushrooms unilaterally sourced from the surrounding woodlands are common sights in many village or local markets in West Africa. Proper inventory of diverse wild edible and medicinal mushrooms sold in these local markets is required for the development of a mushroom genetic resource germplasm, cultivation of species yet uncultivated, preservation and strain improvement. The ignorance of their domestication knowledge and cultivation technology became the major cause of dependence on mushroom hunting practice. It may also have accounted for the visible underdevelopment of mushroom cultivation practices and undermines their commercial scale production for priority export or foreign exchange generation.

Many wild edible mushrooms are apparently cultivated at a subsistent level due to the extension initiatives of agro-based and donor-funded agencies with a priority focus on eradicating hunger and poverty among the West African people. Lentinus squarrosulus, Volvariella volvacea, Psathyrella sp, Pleurotus tuber-regium, Pleurotus pulmonarius, Pleurotus ostreatus, Schizophyllum commune are examples of mushrooms (Figure 2) that are cultivated using low-cost technology in both urban and rural parts of West Africa [66,67]. Despite this, no part of the region is on the world list of largest exporters and commercial producers of edible and medicinal mushrooms, and familial mushroom products [68]. The number of edible mushrooms successfully cultivated in the region are few $(<6 \%)$ compared putatively to the over 200 cultivable representative species documented in literatures [69]. There was more ethnomycological accounts of mushrooms that are edible from Bénin, Cameroon, Ghana and Nigeria than any other part of the region (Figure 3) suggesting a large reservoir representative species yet uncultivated in the region. The reason for this limitation and lopsidedness is presently unclear but 

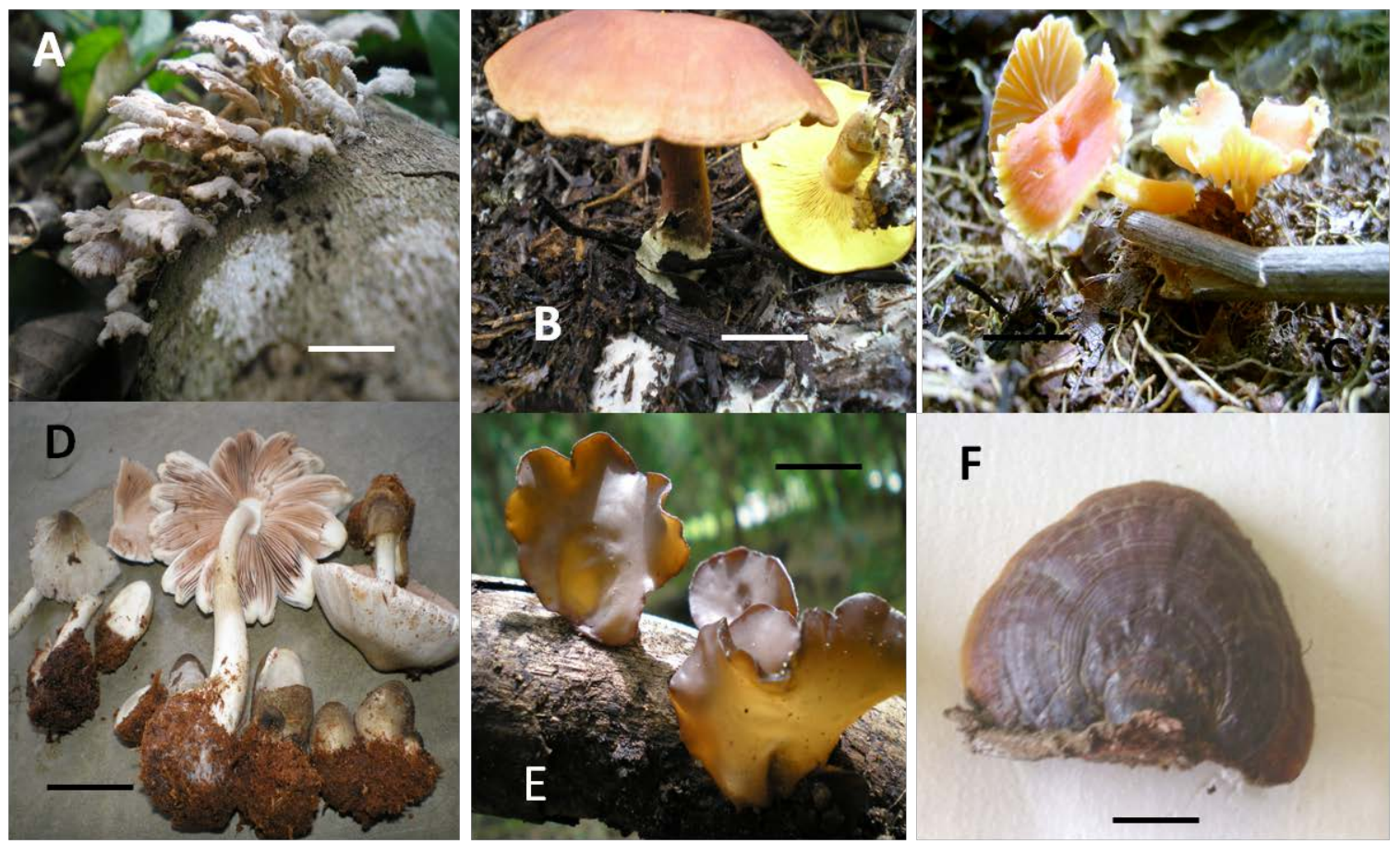

Figure 2. Some popular wild edible and medicinal mushrooms in West Africa. $($ A) $=$ Schizophyllum commune, $(\mathrm{B})=$ Lactarius sp. (C) = Chantarellus platyphyllus, (D) = Volvariella volvacea, $($ E) = Auricularia auricular-Judae, (F) = Ganoderma lucidum. Bar = $1 \mathrm{~cm}$.

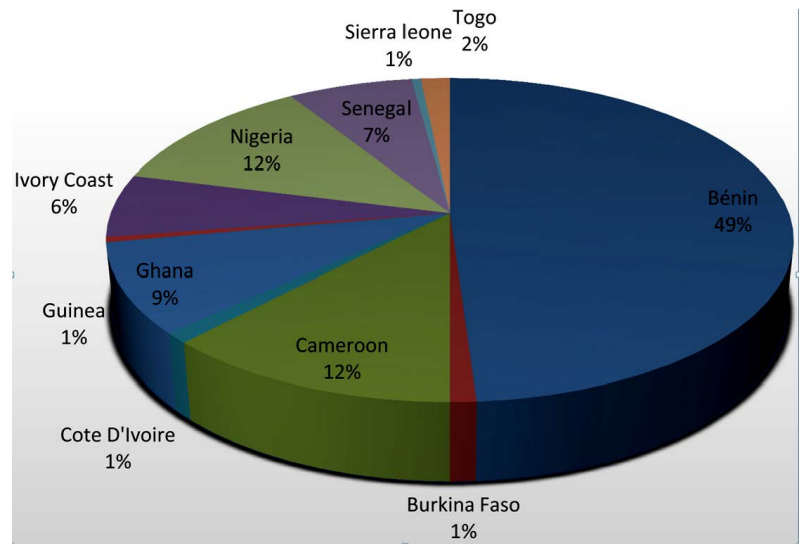

Figure 3. Wild edible and medicinal mushroom distribution across West Africa.

may not be unconnected to the differential level of mushroom literacy, preferential access to information or sponsorship, and influence of cross-country linkages with international experts cum donor agencies. Mushroom cultivation in many rural settlements remained an extraagricultural activity that is practiced at different economic levels ranging from subsistent to small scale business levels. In countries like Cameroon, Bénin and Ghana, portable logs hitherto colonised by mushrooms are relocated from the wild to home gardens where they are nurtured and tendered until the appearance of the next flush (personal communication). This practice equally sufficed as mushroom cultivation which according to
Aguilar et al. [70] can be described as occasional mushroom cultivation. It is characterised by spiralling yield per flush until the log exhausts the food base requirement for mushroom development. In addition, small scale mushroom production are remanded to local bamboo or termite resistant wooden sheds lined with flat topped benches and covered in thatched roofs in shaded locations. The bag mushroom cultivation technology which involves the inoculation of bagged mixture of supplemented or unsupplemented, previously processed, wastes or singly substrate type, and their stacking on well drained bamboo bench is prevalent in the region compared to the log technology (Figure 4). This level of commercial cultivation does not compare with what obtains among the leading global mushroom producers like Canada, USA, China and Mexico where yield per annum is never below 200,000 metric tonnes [16].

Mushrooms are cultivated on diverse available agricultural, industrial and domestic wastes that abound in the region [71]. Wastes of agricultural origin are however more available due to the predominant state of farming and forest related occupations of the inhabitants. The art and advancement in mushroom cultivation especially in rural communities of West Africa underpins its associated social (expansion of traditional diets, improved local communication, relevance and coordination), economic (income, employment opportunities and development) and ecological (reuse of waste, removal of environmental nuisances) benefits. Mushroom produc- 

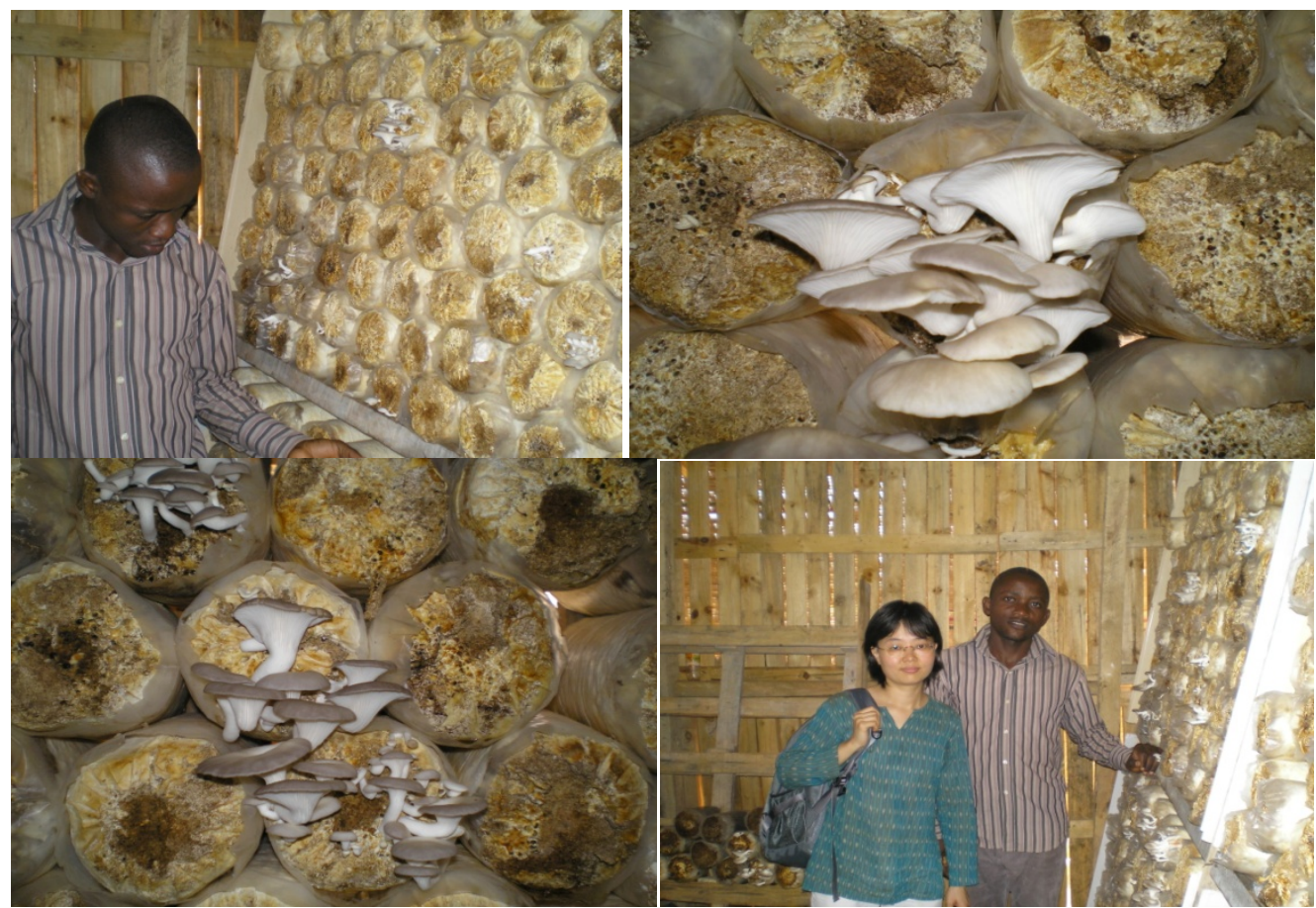

Figure 4. Pleurotus ostreatus cultivation cottage visited during the 2009 Africa Society for Edible and Medicinal Mushroom (ASEMM) Conference in Ghana (Picture by Osemwegie, 0.0 .).

tion in the region is apparently recent and still at its infancy. Consequently, improvement is required on the present nature of technical knowledge for sustainable mushroom yield, and their exploitation for production of single cell proteins, animal feed supplements and biofertilizers in integrated agriculture system. The ease of maintaining (low-cost) mushroom cultivation, availability of requisite raw materials (substrates of diverse origin) coupled with limited human resource involvement in its production coupled with ready market for the harvested mushrooms are characteristics of mushroom cultivation process.

It is imperatively clear that the positive transformation of edible mushrooms' domestication in the region requires an integrative government support and priority review of governments' sponsored programs and policies. Devolving some of the World Bank assisted fund meant for agricultural development to the organization of mushroom cultivation training for the suburban people could be a partial resolution to national poverty, and consequently empower youths and women. This is in addition to diversifying food production focus and enhancing community's capacity to cope with economic opportunities. While the popularization of mushroom cultivation and its associated benefits cannot be over-emphasised, it may provide an indirect opportunity for national foreign exchange earnings and food security challenges in the region and deconcentrate economic reliance on crude oil revenues. Mushroom production farms are however scarce and inadequate to meet the ever growing demands for mushrooms even by the hitherto mycophobic city settlers. The involvement of the rural communities and their local knowledge base in edible mushroom cultivation encourage improvement, conceptualization and experimentations of commodification in the region. More ethnomycological, biodiversity and chemistry works is therefore required to move West Africa to a place of global recognition in mushroom activities.

\section{Scope of Utilization}

The use of mushrooms as accessible food and in folk medicine practice predates all other usage underpinning their economic importance to humans [18]. West African region is characterized by many communities with long history of mushrooms usage in these wise. Although, the ancestral or historical origin of mycophagy and mushroom uses in folk medicine practice across Africa and Asia is currently unknown but it was presumed to sequent human existence. The growing popularity of mushroom usages therefore underscores the need for their domestication and commodification [33]. The evolution of the technical knowledge for mushroom cultivation was a product of humans' need to conquer their seasonality, reduce mushroom hunting risks and meet growing food demands for diverse culinary mushrooms. Theoretically, the growing practice of mushroom cultivation endangers the traditional essence of indigenous cultural knowledge 
heritage [72]. This is in addition to eroding the inherent perception associating mushrooms with the less privileged and relatively poor locals who cannot afford animal protein diets. The changing climate, growing human population, pollution, human occupational activities (hunting, fruit and firewood gathering, bush burning, agriculture methods, logging etc.) and urbanization have putatively depleted mushrooms' genetic resource. This consequently limits the location of mushrooms further afield, deeper into forests and other woodlands demands more incalculable hunting efforts, but does not diminish mushroom hunting habit and reliance on the wild for edible mushrooms among West African rural communities. Personal communication with local tribes' men in some parts of Nigeria showed that this practice is sustained on the generalist perception that wild edible mushrooms are fresh (pristine) and genetically unmodified in nature with texture associated more with meat rather than vegetables. In addition, others opined that wild edible species of mushrooms are preferentially more tasteful, palatability and nutritious (protein, dietary fibre, mineral and vitamine) than their cultivated counterparts [2]. Although, reports abound that suggested a positive link between mushrooms' phytochemical contents and mineral characteristics of their ambient environment (or habitat), further studies is required for better comprehension [46].

While mushrooms are popular as nutrient foods and are becoming an important source of income especially in Africa, their mythological and mystical uses as well as associated knowledge base is becoming limited by civilization. This is corroborated by Boa [16] who reported over 1200 species of macrofungi used in about eightyfive different countries of the world for food and medicinal purposes only. Many other novel and innovative uses of mushrooms are reported in more developed parts of the world that are elusive in most West African tribes. Challenging mutually exclusive factors including poor information access, level of illiteracy, poverty and local beliefs could have accounted for this. Conversely, mushrooms are revered in China, Mexico, USA and Canada as a means of foreign exchange, in integrated health care provisions (blend of ancient traditional with modern orthodox therapies), agriculture, poetry, art, vocations, culinary and industries [4,73]. In West Africa, the use of mushrooms and corresponding knowledge heritage is rapidly disappearing even in native medicine practice typical of many rural communities without access to modern health care facilities. Folk healing in the region is predominated by the use of plants rather than mushrooms. Idu and Osemwegie [65] attributed this to the seasonality of mushrooms and the putative conception relating therapeutic potency to size or quantity of readily available herbal materials. Consequently, documented evidences of drugs produced from mushrooms are seldom associated with the region compared to what obtains in some developed countries.

The mythological and mystical uses (entheogenic) of mushrooms are common in West Africa with relatively more documentary evidences from Nigeria compared with other parts of the region [18,40,74]. Although, these uses are presently becoming blurred and subverted by widespread civilization, mushrooms are however still marginally appreciated for mythological and religious purposes compared to uses in folk therapies. Proofs of these uses may be limited in ethnomycological literatures from the West African region, it has nevertheless been theoretically demonstrated in traditional rituals e.g. voodooism, shamanism and idolatry and other religious worships in Ghana, Bénin, Cameroon, Nigeria and Togo [26, 30,48].

Mushrooms were reported to contain stimulatory, toxigenic, hallucinogenic and lethal properties that could create mycophobia in humans. These properties impelled the global medicinal uses of mushrooms as psychoactive, antibiotics, immunomodulators, anticholesterol, antihypertensive and longevity drugs. The hallucinogenic and stimulatory properties of some mushrooms is explored in communicating with the gods and/or lesser spirits, and even in traditional dances as reported in literature $[6,46$, 74]. An organized network of mycologists may become an effective force in explorative experimentations using African mushrooms. Furthermore, it fosters the transmutation and adaptation of documented uses in the resolution of food, medical, agricultural and industrial challenges.

\section{Factors Militating against the Development of Ethnomycological Studies}

The poor, inchoate and inconsistent state of West African ethnological data in scientific literatures has created a huge gap in global biodiversity estimation, representation and distribution of fungi, especial mushrooms. Logically, most of the factors are connected to the lifestyle and tradition of the human clans. Inherited indigenous knowledge of edible and/or poisonous mushrooms, their corresponding uses and information hoarding may be discouraging to empirical ethnomycology studies while underscoring the need for clearer understanding of the sociological dynamics between human and fungi. Evolutionary (adaptational) changes and ecosystem dynamics that selectively conferred potential values on previously valueless taxa could not also be ignored. Consequently, the wild remains a self-adjusting pool of valuable genetic resources. Most common, widespread generalist species have uses already documented in literatures even though 
under-exploited while others perhaps uninvestigated have cryptic uses. The West African region is apparently regarded by Myer et al. [75] as a potential hotspot for novel biogenetic resources (mushrooms inclusive) of value to humans and a conservation priority. This contrasted greatly with the world distribution and volume of useful taxa reported by [16].

Political, academic, infrastructural and economic factors could militate against the development of ethnomycological studies and reportage from the region. Technical supports from international experts toward the development of effective mushroom cultivation aptitude and altitude are rare compared to what obtains in many eastern, central and south African nations. This could have been the resultant effect of poor linkage opportunities by appropriate agencies or researchers. Like it was mentioned earlier, disinterest in mushroom research also affects negatively the creation of linkage opportunities that will attract donor-fund for the preservation of indigenous mushroom knowledge, enrichment of extant knowledge, revision of diversity data and their associated utility, and report of ethnomycological studies in West African region. The source of research disinterest in ethnomycology is currently vague but may have sprouted from the dichotomous mushroom culture which may be uniquely mycophilic or mycophobic. Nakalembe et al. [8] and Garibay-Orijel et al. [7] corroborated this fact while also recognizing the fundamental direct influence of the healthy state and functionality of ambient forest ecosystems on mushroom culture and consequently the state of ethnomycology.

The characteristic rainfall distribution pattern of the region has constrained mushroom cultivation and encourages mushroom hunting of available edible species which are picked and eaten or sold. Suffice to say mushroom hunting like game hunting in many of the nations within the scope of this study is not yet regulated by any legislation except in isolated national parks and forest reserves. There is also no documented account of red-list of any endangered African edible mushroom in the region. Governments in these areas of Africa hold the erroneous believe that mushrooms are either irrelevant in human development or worthless. This perception has affected negatively government funding of mushroom projects and research compared to other food crops in the region. Attempts by some international bodies such as United State Agency for International Development (USAID), Food and Agricultural Organization (FAO) and occasionally under the aegis of Global Network, ASEMM to improve agriculture, and mushroom cultivation research were theoretically skewed.

The level of poverty among the people does not also support research and development with relations to mushrooms. Many trained mycologist working in the region grapple with the consequences of low income, poor state of social, communal, religious and political crisis, anarchy, corruption, and spiralling education budget and standard. A few rural communities in the West African sub-region, especially those encamped around forests have had discordance with government over sacrificing the relatively pristine vegetation with its attendant spacial climate for urbanization without corresponding reparative and compensative measures. This has forced most community leaders to be leery of strangers on survey and/or academic research missions. Interaction with fellow ethnomycology researchers proved the response of mistrust during field information gathering for ethnomycological research. This has invariably undermines ethnomycological research outputs, quality and interests. In addition, it confounded the documentation of indigenous knowledge of medicinal mushrooms used in folk health therapies and invariable became the direct cause of the cultural practice of secrecy and extortion on profitable knowledge about wild mushrooms [48]. Hoarding of information from non-nuclear family members that is relating to 1 ) the location for collecting viable edible mushroom, 2) mushroom cuisines, 3) types of mushrooms used in folk medicinal application and 4) on rare instances mushroom poisoning encounter, is perceived generally to confer differential economic advantage on those who had the benefits of such knowledge as corroborated by Volpato et al. [33] and Lampman [2].

\section{Conclusions}

The reportage of ethnomycological studies and its spread across the West African sphere is comparatively poor while indigenous mushroom knowledge of the region faces the risk of extinction due to poor pace of empirical data collection. This review which creates consciousness for the encouragement of more research publications that can firstly unravels the complex mystery of humanmushroom relationship. Secondly, it systematically draws attention to the variation in mushroom culture as a basis for comparing and contrasting the state of ethnomycology in other parts of Africa. Commodification, although of vague geneology with recent reportage in mycological literature has influenced changes in the cultural behaviour of the West African people, inter-cultural mix and traditional food base. While this paper discussed sparingly the extent of the use of mushrooms in integrated folk medicine and mythological practices of the West African people, it does recognized their significance in modelling mycophilic behaviour and expanding mushroom demands. In addition, the seasonality of mushrooms which naturally affect their utility in many places like the Mexico [7], Uganda [8] and Philipines [76] were observed to have little to almost insignificant impact on mycophagy cul- 
ture due to longer months of rainfalls and wide area of tropical broad-canopy woodlands spread that characterized West African region. Folk beliefs about the right ecological niche (ethnoecology) that confirms a mushroom fit for consumption are sketchy and mere fables as this have been scientifically disproven. Further research may however be required to affirm the concept highlighted by this paper on the corresponding effect of a polluted environment on the level of poison or toxic constituents of any mushrooms and its eventual classification as poisonous or safe to eat and/or West African ethnography relative to mushroom uses.

Ethnomycology worldwide is broadening in scope and design that now addresses the knowledge base across gender, age groups and occupational categories. The enumeration of medicinal or nutrion and numerous other useful mushrooms that have found relevance in the advancement of human livelihood has dominated mycological literature. Understanding novel technical knowledge that could be deployed for the successful cultivation of hitherto uncultivated edible and other valuable mushrooms underpins the need for further research. Equally, the sociological and anthropological perspectives to the dynamic of mushroom utilization and the spread across the region also call for a concerted research network. This paper therefore represents the first attempt to present a coordinated review/chronicle of ethnomycological works from the West Africa.

\section{REFERENCES}

[1] A. De Kesel and J. Degreef, "Ethnomycological Research and Literature Surveys from Africa," MycoAfrica, Vol. 2, No. 1, 2007, pp. 4-5.

[2] M. A. Lampman, "How Folk Classification Interacts with Ethnoecological Knowledge: A Case Study from Chiapas Mexico,” Tzeltal Ethnoecology, Vol. 14, No. 1, 2010, pp. 39-51.

[3] U. G. Menini, "Issues for Global Cooperative Program on Identification, Conservation, Evaluation and Utilization of Mushroom Genetic Resources,” In: J. E. Labarère and U. G. Menini, Eds., Proceedings of the First International Congress for the Characterization, Conservation, Evaluation and Utilization of Mushroom Genetic Resources for Food and Agriculture, Bordeaux, 2000.

[4] S. P. Wasser, "Current Findings, Future Trends, and Unsolved Problems in Studies of Medicinal Mushrooms," Applied Microbiology and Biotechnology, Vol. 89, No. 5, 2010, pp.1323-1332. http://dx.doi.org/10.1007/s00253-010-3067-4

[5] R. Wasson, “The Wondrous Mushroom,” McGraw-Hill, 1980.

[6] D. Arora and S. H. Glenn Jr., "Mushrooms and Economic Botany,” Economic Botany, Vol. 62, No. 3, 2008, pp. 207212. http://dx.doi.org/10.1007/s12231-008-9046-3

[7] R. Garibay-Orijel, A. R. Terrazo and M. Ordaz-Valáz- quez, "Women Care about Local Knowledge, Experiences from Ethnomycology," Journal of Ethnobiology and Ethnomedicine, Vol. 8, 2012, pp. 25-37. http://dx.doi.org/10.1186/1746-4269-8-25

[8] I. Nakalembe, D. Kabasa and D. Olila, "Indigenous Knowledge and Usage of Wild Mushrooms in MidWestern, Uganda,” African Journal of Animal and Biomedical Sciences, Vol. 4, No. 2, 2009, pp. 63-73.

[9] A. Tsing, "Unruly Edges: Mushrooms as Companion Species," Environmental Humanities, Vol. 1, 2012, pp. 141154.

[10] W. L. Traill, C. T. Wanger, S. C. De Little and W. K. Brook, "Rainfall and Temperature Variation Does Not Explain Arid Species Diversity in Outback Australia," Research and Reports in Biodiversity Studies, Vol. 3, 2013, pp. 1-8.

[11] H. Kauserud, C. L. Stige, O. J. Vik, R. H. Okland, K. Hoiland and C. N. Stenseth, "Mushroom Fruiting and Climate Change," Proceedings of the National Academy of Science, Vol. 105, No. 10, 2008, pp. 3811-3814. http://dx.doi.org/10.1073/pnas.0709037105

[12] D. L. Hawksworth, "Limitation of Dual Nomenclature for Pleomorphic Fungi,” Taxon, Vol. 53, 2004, pp. 596-598. http://dx.doi.org/10.2307/4135654

[13] D. L. Hawksworth, "The Magnitude of Fungal Diversity: The 1.5 Million Species Estimate Revisited,” Mycological Research, Vol. 105, 2001. pp. 1422-1432. http://dx.doi.org/10.1017/S0953756201004725

[14] G. M. Mueller, J. P. Schmit, P. R. Leacock, B. Buyck, J. Cifuentes, D. E. Desjardin, R. E. Halling, K. Hjortstam, T. Iturriaga, K. H. Larsson, D. J. Lodge, T. W. May, D. Minter, M. Rajchenberg, S. A. Redhead, L. Ryvarden, J. M. Trappe, R. Watling and Q. X. Wu, "Global Diversity and Distribution of Macrofungi,” Biodiversity and Conservation, Vol. 16, No. 1, 2007, pp. 37-48. http://dx.doi.org/10.1007/s10531-006-9108-8

[15] A. Y. Rossman, "A Strategy for the All-Taxa Inventory of Fungal Biodiversity,” In: C. I. Peng and C. H. Chou, Eds., Biodiversity and Terrestrial Ecosystems, Academia Sinica Monograph Series No. 14, Taipei, 1994, pp. 169-194.

[16] E. Boa, "Wild Edible Fungi. A Global Overview of Their Use and Importance to People," Non-Wood Forest Products Series No. 17, Rome, 2004.

[17] G. Germishuizen and N. L. Meyer, "Plants of Southern Africa: Annotated Checklist,” Strelitzia, Vol. 14, 2003, pp. 1211-1231.

[18] J. A. Okhuoya, E. O. Akpaja, O. O. Osemwegie, A. O. Oghenekaro and C. A. Ihayere, "Nigeria Mushrooms: Underutilized Non-Wood Forest Resources," Journal of Applied Science and Environmental Management, Vol. 14, No. 1, 2010, pp. 43-54.

[19] T. C. Sarma, I. Sarma and B. N. Patiri, "Wild Edible Mushrooms Used by Some Ethnic Tribes of Western Assam,” The Bioscan, Vol. 3, 2010, pp. 613-625.

[20] S. M. Ayodele, E. O. Akpaja and Y. Adamu, "Some Edible and Medicinal Mushrooms of Igala Land in Nigeria, Their Sociocultural and Ethnomycological Uses," International Journal of Science and Nature, Vol. 2, No. 3, 
2011, pp. 473-476.

[21] T. R. Kinge, E. M. Tabi, A. M. Mih, E. A. Egbe, L. A. Njouonkou and T. M. Nji, "Ethnomycology Studies of Macrofungi (Mushrooms) in Mount Cameroon Region,” International Journal of Medicinal Mushrooms, Vol. 13, 2011, pp. 299-305.

http://dx.doi.org/10.1615/IntJMedMushr.v13.i3.100

[22] M. Gryzenhpout, M. J. Jefwa and S. N. Yorou, “The Status of Mycology in Africa: A Document to Promote Awareness,” IMA Fungus, Vol. 3, No. 1, 2012, pp. 99102. http://dx.doi.org/10.5598/imafungus.2012.03.01.11

[23] M. E. Nwordu, R. U. Isu and G. H. Ogbadu, "Catalogue and Identification of Some Wild Edible Macrofungi in Nigeria," Online International of Food Science, Vol. 2, No. 1, 2013, pp.1-15.

[24] A. Kouassi, I. B. F. Fofana, F. Bois and J. E. Labarére, "Collection and Preservation of Mushroom Genetic Resources in Ivory Coast, for Their Utilization for Food and Agriculture,” In: J. E. Labarère and U. G. Menini, Eds., Proceedings of First International Congress for the Characterization, Conservation, Evaluation and Utilization of Mushroom Genetic Resources for Food and Agriculture, Bordeaux, 2000.

[25] K. M. L. Guissou, A. M. Lykke, P. Sankara and S. Guinko, "Declining Wild Mushroom Recognition and Usage in Burkina Faso,” Economic Botany, Vol. 62, No. 3, 2008, pp. 530-539. http://dx.doi.org/10.1007/s12231-008-9028-5

[26] J. E. Labarère and U. G. Menini, "Collection, Characterization, Conservation and Utilization of Mushroom Germplasm Resources in Africa,” In: J. E. Labarère and U. G. Menini, Eds., Proceedings of First International Congress for the Characterization, Conservation, Evaluation and Utilization of Mushroom Genetic Resources for Food and Agriculture, Bordeaux, 2000.

[27] P. W. Crous, I. H. Rong, A. Wood, S. Lee, H. Glen, W. Botha, B. Slippers, W. Z. De Beer, M. J. Wingfield and D. L. Hawksworth, "How Many Species of Fungi Are There at the Tip of Africa?” Studies in Mycology, Vol. 55, No. 1, 2006, pp. 13-33. http://dx.doi.org/10.3114/sim.55.1.13

[28] H. V. Dijk, N. A. Onguene and T. W. Kuyper, "Knowledge and Utilization of Edible Mushrooms by Local Population of the Rain Forest of South Cameroon," Ambio, Vol. 321, 2003, pp.19-23.

[29] K. Yongabi, M. Agho and D. C. Martinez, "Ethnomycological Studies on Wild Mushrooms in Cameroon, Central Africa," Micologia Aplicada International, Vol. 16, No. 2, 2004, pp. 34-36.

[30] T. R. Kinge, E. A. Egbe, E. M. Tabi, T. M. Nji and A. M. Mih, "The First Checklist of Macrofungi of Mount Cameroon,” Mycosphere, Vol. 4, No. 4, 2013, pp. 694-699. http://dx.doi.org/10.5943/mycosphere/4/4/5

[31] M. Dzomeku, "Studies on the Occurrence, Ethnomycology and Cultivation of Pleurotus tuber-regium," A PhD Dissertation, Department of Theoretical and Applied Biology, Kwame Nkrumah University of Science and Technology, Kumasi, 2009, 152 p.

[32] A. De Kesel and A. Guelly, "Séminaire de Mycology. Togo (Afrique d l'Quest) du 2 au 26 Juillet 2007,” Final
Report Global Taxonomy Initiative Project GTI/ExtC/ 2007.10/De Kesel, National Botanic Garden, Belgium, 2007, 43 p.

[33] G. Volpato, D. Rossi and D. Dentoni, “A Reward for Patience and Suffering: Ethnomycology and Commodification of Desert Truffles among Sahrawi Refugees and Nomads of Western Sahara,” Economic Botany, Vol. 67, No. 2, 2013, pp. 147-160. http://dx.doi.org/10.1007/s12231-013-9234-7

[34] J. Rammeloo and R. Walleyn, "The Edible Fungi of Africa South of the Sahara: A Literature Survey," Scripta Botanica Belgica, Vol. 5, 1993, pp. 1-62.

[35] A. De Kesel, J. T. C. Codjia and S. N. Yorou, "Guide des Champinons Comestibles du Bénin. Centre International d'Ecodéveloppement Intégré (CECODI)," Coco-Multimedia, Cotonou, République du Bénin, National Botanic Garden, Belgium, 2002, 74 p.

[36] N. S. Yorou, A. De Kesel, B. Sinsin and J. T. C. Codjia, "Diversity and Productivity of Edible Wild Mushrooms in Benin (West Africa)," Systematics and Geography of Plants, Vol. 71, No. 2, 2002, pp. 613-625. http://dx.doi.org/10.2307/3668706

[37] A. A. Walker, "Champignons Comestibles de la BasseNgounié (Gabon),” Revue de Biologie Appliqué et d'Agriculture Tropicale, Vol. 11, 1931, pp. 240-247.

[38] M. H. Zoberi, “Tropical Macrofungi,” Macmillian Press Ltd, London, 1972.

[39] M. H. Zoberi, "Some Edible Mushrooms from the Tropics,” Mushroom Science, Vol. 10, No. 2, 1979, pp. 519536.

[40] B. A. Oso, "Mushrooms and the Yoruba People of Nigeria,” Mycologia, Vol. 67, No. 2, 1975, pp. 311-319. http://dx.doi.org/10.2307/3758423

[41] B. A. Oso, "Mushrooms in Yoruba Mythology and Medicinal Practices,” Economic Botany, Vol. 31, No. 3, 1977, pp. 367-371. http://dx.doi.org/10.1007/BF02866888

[42] S. O. Isikhuemhen and J. A. Okhuoya, "Cultivation of Pleurotus tuberregium (Fr.) Singer for Production of Edible Sclerotia on Agricultural Wastes,” In: D. J. Royse, Ed., Proceedings of the 2nd International Conference on Mushroom Biology and Mushroom Products, Pennsylvania State University, University Park, 1996.

[43] S. Kaewchai, K. Soytong and K. D. Hyde, "Mycofungicides and Fungal Biofertilizers," Fungal Diversity, Vol. 38, 2009, pp. 25-50.

[44] O. O. Osemwegie, S. O. Ekaye and I. C. Ntekume, “The Effect of Grower Feed Diet Supplement with Ganoderma lucidum against Some Enteric Zoonotic Parasites of Pigeons (Columba livia),” Biokemistri, Vol. 24, No. 3, 2012, pp. 129-135.

[45] E. Boa, "From Chipho to Msika: An Introduction to Mushrooms, Trees and Forest,” In: A. Cunningham and X. F. Yang, Eds., Mushrooms in Forests and Woodlands: Resource Management, Values and Local Livelihoods, Earthscan, London, 2010, pp. 1-20.

[46] M. De Román, E. Boa and S. Woodward, "Wild-Gathered Fungi for Health and Rural Livelihoods," Proceedings of the Nutrition Society, Vol. 65, No. 2, 2006, pp. 190-197. 
http://dx.doi.org/10.1079/PNS2006491

[47] A. De Kesel and N. S. Yorou, "Preliminary Studies of Higher Fungi Associated with Woodlands in North Benin,” Scripta Botanica Belgica, Vol. 20, 2000, p. 26.

[48] E. O. Akpaja, S. O. Isikhuemhen and J. A. Okhuoya, "Ethnomycology and Usage of Edible and Medicinal Mushrooms among the Igbo People of Nigeria,” International Journal of Medicinal Mushrooms, Vol. 5, No. 3, 2003, pp. 313-319. http://dx.doi.org/10.1615/InterJMedicMush.v5.i3.100

[49] D. D. Tibuhwa, "Folk Taxonomy and Use of Mushrooms in Communities around Ngorongoro and Seregeti National Park, Tanzania," Journal of Ethnobiology and Ethnomedicine, Vol. 8, 2012, p. 36 http://dx.doi.org/10.1186/1746-4269-8-36

[50] M. H. Zoberi, "Some Edible Mushrooms from the Tropics," Mushroom Science, Vol. 10, No. 2, 1978, pp. 519-536.

[51] A. De Kesel, A. K. Guelly, N. S. Yorou and J. C. Codjia, "Ethnomycology Notes on Maraamiellus inoderma from Benin and Togo (West Africa)," Cryptogamie Mycologie, Vol. 29, No. 4, 2008, pp. 313-319.

[52] L. Svoboda, K. Zimmermannová and P. Kalac, "Concentartions of $\mathrm{Hg}, \mathrm{Cd}, \mathrm{Pb}$ and $\mathrm{Cu}$ in Fruiting Bodies of Edible Mushrooms in an Emission Area of $\mathrm{Cu}$ Smelter and a Hg Smelter," The Science of the Total Environment, Vol. 246, No. 1, 2000, pp. 61-67. http://dx.doi.org/10.1016/S0048-9697(99)00411-8

[53] S. Caillon and P. Degeorges, "Biodiversity: Negotiating the Border between Nature and Culture," Biodiversity and Conservation, Vol. 16, No. 10, 2007, pp. 2919-2931. http://dx.doi.org/10.1007/s10531-007-9149-7

[54] L. I. Norvell, "Melbourne Approves a New Code," Mycotaxon, Vol. 116, 2011, pp. 481-490. http://dx.doi.org/10.5248/116.481

[55] D. L. Hawksworth, P. W. Crous, S. A. Redhead, D. R. Reynolds, R. A. Samson, K. A. Seifert, J. W. Taylor and M. J. Wingfield, "The Amsterdam Declaration on Fungal Nomenclature,” IMA Fungus, Vol. 2, No. 1, 2011, pp. 105-112.

[56] R. H. Kurtzman, "Mushrooms in Developing Countries2008,” Micologia Aplicada International, Vol. 21, No. 1, 2008, pp. 37-42.

[57] M. Obodai and M. Apetorgbor, “An Ethnobotanical Study of Mushroom Germplasm and Its Domestication in the Bia Biosphere Reserve of Ghana,” Report Presented to UNESCO through Environmental Protection Agency of Ghana, Accra, 2001.

[58] D. N. Pegler and M. Vanhaeck, "Termitomyces of Southeast Asia,” Kew Bulletin, Vol. 49, No. 4, 1994, pp. 717736. http://dx.doi.org/10.2307/4118066

[59] R. Walleyn and J. Rammeloo, "The Poisonous and Useful Fungi of Africa South of the Sahara: A Literature Survey,” Scripta Botanica Belgica, Vol. 10, 1994, pp. 1-56.

[60] D. C. Mossebo, A. Amougou and R. E. Atanga, "Contribution à L'étude du Genre Termitomyces (Basidiomycétes) au Cameroun: Écologie et Systématique,” Bulletin de la Société Mycologique de France, Vol. 118, No. 3, 2002, pp. 195-249.
[61] J. Gbolagade, A. Ajayi, I. Oku and D. Wankasi, "Nutritive Value of Common Wild Edible Mushrooms from Southern Nigeria," Global Journal of Biotechnology and Biochemistry, Vol. 1, No. 1, 2006, pp. 16-21.

[62] K. B. Sanon, A. M. Ba and J. Dexheimer, "Mycorrhizal Status of Some Fungi Fruiting Beneath Indigenous Trees in Burkina Faso,” Forest Ecology and Management, Vol. 98, No. 1, 1997, pp. 61-69.

http://dx.doi.org/10.1016/S0378-1127(97)00089-3

[63] O. V. Oyetayo, "Medicinal Uses of Mushrooms in Nigeria: Towards Full and Sustainable Exploitation,” African Journal of Traditional, Complement and Alternative Medicine, Vol. 8, No. 3, 2011, pp. 267-274.

http://dx.doi.org/10.4314/ajtcam.v8i3.65289

[64] T. N. Ling, J. I. Okogun and W. R. Folk, "21st Century Natural Product Research and Drug Development and Traditional Medicines,” Natural Product Reports, Vol. 30, No. 4, 2013, pp. 584-592. http://dx.doi.org/10.1039/c3np20120a

[65] M. Idu and O. O. Osemwegie, "Some Medicinal Flora of Okomu Forest Reserve in Southern Nigeria," Research Journal of Medicinal Plant, Vol. 1, No. 1, 2007, pp. 29-31. http://dx.doi.org/10.3923/rjmp.2007.29.31

[66] O. O. Osemwegie, S. O. Isikhuemhen, O. J. Onyolu and J. A. Okhuoya, "Cultivation of Selected Sporophore-OnlyProducing Strain of the Edible and Medicinal Mushrooms; Pleurotus tuber-regium (Fr.) Singer (Agaricomycetideae) on Waste Papers and Plantain Peelings," International Journal of Medicinal Mushrooms, Vol. 4, No. 4, 2002, pp. 343-348.

[67] F. Alemawor, V. P. Dzogbefia, E. O. K. Oddoye and J. H. Oldham, "Effect of Pleurotus ostreatus Fermentation on Cocoa Pod Husk Composition: Influence of Fermentation Period and $\mathrm{Mn}^{2+}$ Supplementation on the Fermentation Process,” African Journal of Biotechnology, Vol. 8, No. 9, 2009, pp. 1950-1958.

[68] P. B. Flegg, "Future Strategies for Mushroom Production," Mushroom Research, Vol. 1, 1992, pp. 13-18.

[69] E. Marshall and N. G. Nair, "Make Money by Growing Mushrooms," FAO Diversification Booklet Number 7, FAO, Rome, 2009, 64 p.

[70] A. Aguilar, D. Martinez-Carrera, A. Marcias, M. Sánchez, L. I. De Bauer and A. Martinez, "Fundamental Trends of Rural Mushroom Cultivation in Mexico, and Their Significance for Rural Development," Proceedings of the IV International Conference on Mushroom Biology and Mushroom Products, Cuernavaca, Mexico, 2002, pp. 421-431.

[71] J. A. Okhuoya, "Raw Materials for Mushroom Substrate Preparation in Developing Countries,” In: J. E. Labarère and U. G. Menini, Eds., Proceedings of First International Congress for the Characterization, Conservation, Evaluation and Utilization of Mushroom Genetic Resources for Food and Agriculture, FAO, Bordeaux, 2000.

[72] M. J. Samways, "Rescuing the Extinction of Experience," Biodiversity and Conservation, Vol. 16, No. 7, 2007, pp. 1995-1997. http://dx.doi.org/10.1007/s10531-006-9144-4

[73] H. P. Molitoris, "Mushroom in Medicine, Folklore and Religion,” Fedde Repertorium, Vol. 113, 2002, pp. 165- 
182.

[74] D. O. Osagualekhor and J. A. Okhuoya, "Sociocultural and Ethnomycological Uses of Mushrooms among the Esan People of Nigeria," International Journal of Medicinal Mushrooms, Vol. 7, No. 3, 2005, pp. 442-443. http://dx.doi.org/10.1615/IntJMedMushr.v7.i3.810

[75] N. Myers, R. A. Mittermeier, C. G. Mittermeier, G. A. B. Da Fonseca and J. Kent, "Biodiversity Hotspots for Con- servation Priorities,” Nature, Vol. 403, 2000, pp. 853-858. http://dx.doi.org/10.1038/35002501

[76] A. M. De Leon, R. G. Reyes and D. Cruz Tee, “An Ethnomycological Survey of Macrofungi Utilized by Aeta Communities in Central Luzon, Phillipines," Mycosphere, Vol. 3, No. 2, 2012, pp. 251-259.

http://dx.doi.org/10.5943/mycosphere/3/2/9 